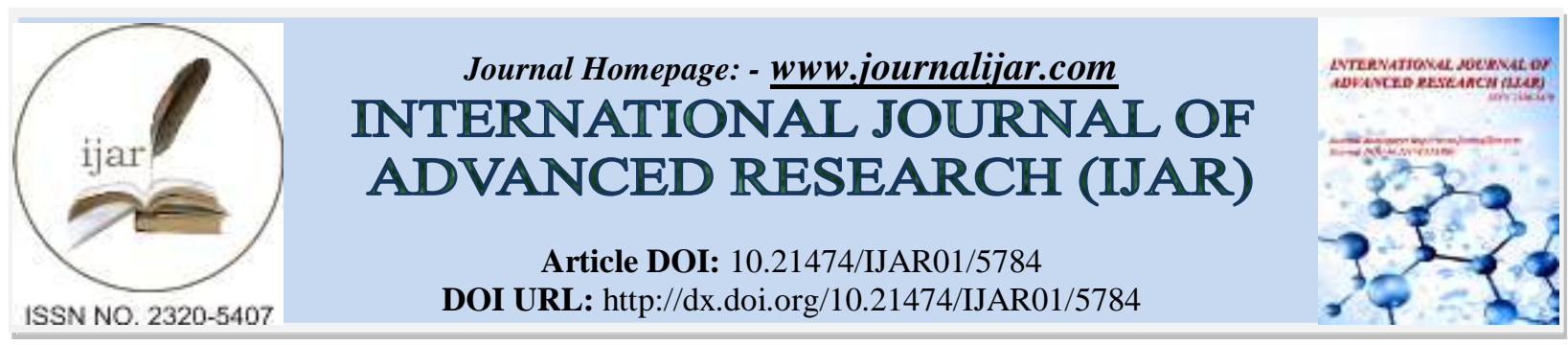

RESEARCH ARTICLE

\title{
CLUSTER APPROACH FOR DEVELOPMENT OF MSME SECTOR IN INDIA
}

\author{
Dr. Shashikant magar.
}

\section{Manuscript Info}

Manuscript History

Received: 06 September 2017

Final Accepted: 08 October 2017

Published: November 2017

Key words:-

MSME, Cluster, Products,

Contribution, Development,

Promotion, Government, industries.

\section{Abstract}

Micro, Small and Medium Enterprises (MSMEs) in India have been evolved considerably since independence of india. Merely from being referred as the Small Scale Industries (SSI) sector in the 60s and 70s, the MSME sector has progressed in large scale and in the scope of business activities over the years. Today, MSMEs are present throughout the sectors (manufacturing, trade and services) in India. Thereby constituting a very formidable component of the country's outstanding economic growth. The key achievement of MSMEs over time has been their talent in utilizing available domestic resources to deliver quality products and services, these firms have made their presence felt across India's key sectors as well as in prominent export markets. MSMEs have also made contribution on a range of issues, from industrial progress to entrepreneurship and from job creation to economic empowerment. It can be felt by the fact that around 50.0 per cent of MSMEs in India are owned by underprivileged groups. Since sector has low capital structure, coupled with high labour absorbing power, the sector has played a noteworthy role in achieving rural industrialization as well. The MSME sector remains a key driving force for India's complete transition from an agrarian economy to an industrialized one. Hence, MSMEs have been awarded a host of incentives by governments across India. A number of other organizations in the private and non-profit domain have also been aiding MSMEs to remain competitive in a more globalised economic order. About MSME it is said it is more scattered and heterogeneous sector. So in order to grow and develop the industry in the sector the cluster approach has taken the birth. Government banks financial institutions are promoting developing encouraging the systematic approach of developing the concept of cluster. The clusters have lot potential. The approach can help for development of MSME as well as industrialization and development of economy.

Copy Right, IJAR, 2017,. All rights reserved.

\section{Introduction:-}

The MSMEs are involved in production of over 6000 products, from simple consumer goods, such as leather articles, plastics and rubber goods, fabrics and ready-made garments, cosmetics, utensils, sheet metal components, soaps and detergents etc. to highly precision and sophisticated end-products, such as television sets, electronic desk calculators, microwave components, air conditioning equipment, electric motors, auto-parts, drugs and 
pharmaceuticals. MSMEs located in different cities/states/regions specialize in manufacture of different kinds, which depends on the availability of skilled manpower and raw material required to manufacture that product. Table below provides list of various products manufactured by MSMEs in different states.

Major Products Manufactured State/UT Wise

\begin{tabular}{|c|c|}
\hline States/UTs & Major Products Manufactured \\
\hline Jammu \& Kashmir & $\begin{array}{l}\text { Processed Food \& Fruits Products, Honey, Woolen show to \& Woolen garments, } \\
\text { Walnut Furniture \& Handicrafts, Handloom Products, Leather Products, and } \\
\text { Mineral based industries, Cricket bats, Wickets, Agro based Industries. }\end{array}$ \\
\hline Himachal Pradesh & $\begin{array}{l}\text { Food Products, Auto Parts and accessories Wood Products, Herbal Products, } \\
\text { Ayurvedic Medicines, Electrical \& Electronic Products, Tourism. }\end{array}$ \\
\hline Punjab & $\begin{array}{l}\text { Food Products, Hosiery, Garments M/C tools \& Components, Rolled steel } \\
\text { products, Cycle \& Cycle parts, Sewing Machinery parts, Milk Products, Basic } \\
\text { metal industries, Woolen Blankets \& Knitwear, Builder's Hardware. }\end{array}$ \\
\hline Chandigarh & $\begin{array}{l}\text { General Engineering, Industrial fasteners, Steel furniture, Auto parts, Steel } \\
\text { fabrication. }\end{array}$ \\
\hline Uttarakhand & $\begin{array}{l}\text { Allopathic \& Ayurvedic Drugs, Engineering Products, Auto Products, Electrical \& } \\
\text { Electronic Products, Survey \& Drawing Instruments, Agro based Products, Tea } \\
\text { Processing, and Tourism. }\end{array}$ \\
\hline Haryana & $\begin{array}{l}\text { Construction Industry, Builder's Hardware, Plywood, Agriculture implements, } \\
\text { Agro based Industry. IT (Software } \\
\text { \& Hardware) }\end{array}$ \\
\hline Delhi & $\begin{array}{l}\text { Garments, Entertainment Electronics, Paper \& Paper Products, General } \\
\text { Engineering Industries, Machine tools \& } \\
\text { Other machinery. }\end{array}$ \\
\hline Rajasthan & $\begin{array}{l}\text { Processed food \& spices, Pickles, Stone cutting \& Stone Handicrafts, Edible Oils, } \\
\text { Wooden Handicrafts \& Furniture,Textiles. }\end{array}$ \\
\hline Uttar Pradesh & $\begin{array}{l}\text { Processed Food Products, Brass Utensils/Brass wares, Bangles, Handicrafts, Hand } \\
\text { woven carpets, Diesel Engines, } \\
\text { Leather Products, Glass wares, Chiken \& Zari work Sarees, Foundry \& Forged } \\
\text { Products, Bamboo \& Wooden furniture, } \\
\text { Hosiery \& other garments, Pottery, Flavors \& Fragrance, Film processing \& } \\
\text { Editing. }\end{array}$ \\
\hline Bihar & $\begin{array}{l}\text { Textiles, Processed food products, Handloom Products, Shellac, and Agro based } \\
\text { products. }\end{array}$ \\
\hline Sikkim & Tea processing, Fruits preservation, Agro based industries, Breweries, Handicrafts. \\
\hline Arunachal Pradesh & $\begin{array}{l}\text { Tea processing, Spices, Cane \& Bamboo products, Timber products, Rubber } \\
\text { product, Carpets, Handicrafts. }\end{array}$ \\
\hline Nagaland & $\begin{array}{l}\text { Sericulture, Mineral Industry, Food processing industry, Agro based industry, } \\
\text { Handicraft, Tourism, Cyber cafés. }\end{array}$ \\
\hline Manipur & Handicrafts, Paper Products, Processed food products, Metal Products, Garments. \\
\hline Mizoram & $\begin{array}{l}\text { Handicrafts, Came \& Bamboo products, STD \& ISD Cyber cafes booth, Food \& } \\
\text { Fruit processing industry, Wooden } \\
\text { furniture, Handloom. }\end{array}$ \\
\hline Tripura & $\begin{array}{l}\text { Food Processing Industry, Tea Processing, Handicrafts \& Handlooms, Iron \& Steel } \\
\text { Fabrications, Rubber Based industry, Forest based industry }\end{array}$ \\
\hline Meghalaya & $\begin{array}{l}\text { Processed food \& Fruit Products, Wood furniture, Garment, Paper \& Painting, } \\
\text { Handicrafts, Cyber Café. }\end{array}$ \\
\hline Assam & $\begin{array}{l}\text { Sericulture, Tea processing, Food Products, Agro Product Processing, Auto } \\
\text { Servicing, Construction Industries, Tiles, } \\
\text { Bricks. }\end{array}$ \\
\hline West Bengal & $\begin{array}{l}\text { Leather Product, Foundry castings (light \& heavy) Rubber and Plastic products, } \\
\text { Small arms, Paper Products, General } \\
\text { Engineering Products \& Machinery parts, Handloom \& Power loom Products, } \\
\text { Hosiery Products, Marine Products, }\end{array}$ \\
\hline
\end{tabular}




\begin{tabular}{|c|c|}
\hline & Film processi \\
\hline Jharkhand & $\begin{array}{l}\text { General Engineering, Auto components, Industrial Fasteners } \\
\text { Maintenance, Shellac. }\end{array}$ \\
\hline Orissa & $\begin{array}{l}\text { Handloom Cotton/Silk Sarees, Marine Product, Handicraft (Metal \& Silver), } \\
\text { Processed food items, Engineering products, Wood based item including boats. }\end{array}$ \\
\hline Chhattisgarh & Agro Products, Fabrication, Food Products. \\
\hline Madhya Pradesh & $\begin{array}{l}\text { Pulse processing, Engineering goods, Leather Toys, Cotton Ginning, Cattle Feed, } \\
\text { Handloom \& Power Loom. }\end{array}$ \\
\hline Gujarat & $\begin{array}{l}\text { Diamond cutting \& Diamond Jewelry, Processed food products, Engineering } \\
\text { Plants, Synthetic \& Silken Textiles, } \\
\text { Chemical Industries, dyes \& Intermediates, Hosiery, Garments, Engineering } \\
\text { Industries. }\end{array}$ \\
\hline Daman \& Diu & Plastics \& Plastic products, Fabrication industries, Wooden furniture. \\
\hline Dadra \& Nagar Haveli & $\begin{array}{l}\text { Plastics products, Engineering items, Paper products, Textiles, Electrical \& } \\
\text { Electronic goods, Fabrication industry. }\end{array}$ \\
\hline Maharashtra & $\begin{array}{l}\text { Entertainment \& Engineering Electronics, Textile \& Textile Products, Chemical \& } \\
\text { Chemical Products, IT (Hardware } \\
\& \text { Soft ware), Auto components, M/C Tools \& Components, Gems \& Jewelry, } \\
\text { Leather Products, Garments, Rubber \& Plastic Products, Marine Products, Foam } \\
\text { Products, Construction Industries, Film processing \& Editing. }\end{array}$ \\
\hline Andhra Pradesh & $\begin{array}{l}\text { Non-ferrous metal products, Pearls \& Jewelry, Marine products, Coir products, } \\
\text { edible oils, Processed food products, Electrical \& Electronic goods, Film } \\
\text { Processing \& Editing }\end{array}$ \\
\hline Karnataka & $\begin{array}{l}\text { Electronics, IT (Software \& Hardware), Cotton \& Silk Handloom Products, Agro } \\
\text { based Industries including sericulture, Telecom \& Telecom Products, Marine } \\
\text { Products, Sandal Oil \& Sandal Carvings, Ivory \& Wood Handicraft, Construction } \\
\text { Industries Tiles etc. }\end{array}$ \\
\hline Goa & $\begin{array}{l}\text { Marine Products, Pharmaceuticals, IT (Software) Electronic goods, Cashews, } \\
\text { Hosiery, Garments, Tourism. }\end{array}$ \\
\hline Lakshadweep & Sea boats, coconut oil \\
\hline Kerala & $\begin{array}{l}\text { Coir \& Coir Products, Marine Products, Cashew, Handloom, Light Engineering, } \\
\text { Rubber \& Rubber Products, Processed food products \& Spices. }\end{array}$ \\
\hline Tamil Nadu & $\begin{array}{l}\text { Hosiery Products, Sericulture, Leather Tanneries \& Leather products, Handicrafts, } \\
\text { Brass wares, General Engineering, } \\
\text { Cotton \& Silk Textiles, Matches \& Fireworks, Marine Products IT (Hardware \& } \\
\text { Soft ware) spices \& agro products, Wind power generation, Film processing \& } \\
\text { Editing. }\end{array}$ \\
\hline Pondicherry & $\begin{array}{l}\text { Chemical products, Cotton, Food products, Rubber products \& Leather products, } \\
\text { Plant products. }\end{array}$ \\
\hline Andaman \& Nicobar & $\begin{array}{l}\text { Handicrafts, Wheat floor, Soft drinks, Fabrication work, Camera Film processing \& } \\
\text { Photo developing, Steel \& } \\
\text { wooden furniture, Marine products. }\end{array}$ \\
\hline
\end{tabular}




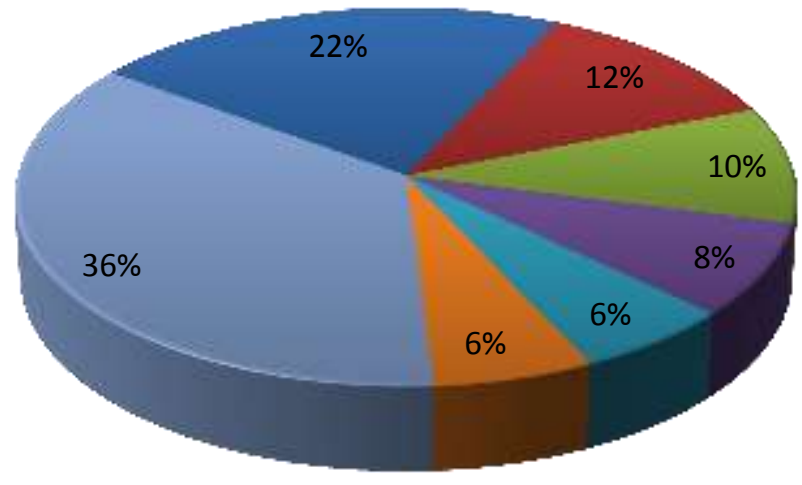

FoodProduct

Chemical\& Chemical Products

Basic Metal Industry

Metal Products

Electrical \& Machinery Parts

Rubber \& plastic Products

Others

There are more than 6000 products ranging from traditional to high-tech items, which are being manufactured by the MSME in India. It is well known that the MSMEs provide the maximum opportunities for both self-employment and jobs after agriculture.

The objective of above analysis leads to giving birth the concept of Cluster culture in Indian MSME sector. The contribution, importance and role of government has been discussed below.

\subsection{Contribution of MSMEs In India towards success to industrial clusters -}

The MSME landscape has matured over time and moved up the value chain. The MSME sector has evolved from the manufacturing of traditional products to much more hybrid products to the value-added services segment. This has been majorly supported by the consortium approach adopted by MSMEs. Due to advent of industrial clusters, Firms in the MSME sector that were earlier facing difficulties in achieving economies of scale, specialization and innovation due to their small size are now increasingly benefitting. Clusters and associated networks enable small firms to combine the advantages of running a small unit with the benefits of scale and specialization provided by large units. Currently, there are more than 600 industrial SMEs clusters and over 7,000 artisan/micro enterprise clusters operating in India. Moreover, there are about 2,500 untapped rural industry clusters in the country. Some of these clusters are so large that they account for nearly 80.0 per cent of production of a selected product within the country. The networking approach has helped MSMEs to overcome barriers such as technological obsolescence, supply chain incompetence, global competition and investment shortages. Furthermore, to capitalise on the benefits from specific target customer base, clusters are classified as export-oriented and specialised domestic ones. Tirupur textile and Vizag marine processing clusters focus mostly on exports. On the other hand, the requirements of large domestic firms are supplied by MSMEs in specialised domestic clusters such as Jamshedpur's engineering cluster and Pune's auto cluster.

\section{0 industrial clusters benefiting to msmes}

The inter-firm linkages stimulated by these clusters and networks have aided MSMEs to move up the value chain and gain competitiveness. At the same time, given greater access to technology and better production coordination techniques in the sector, MSMEs' efficiency has significantly improved. This would provide them with greater business viability. Given this greater sense of sustainability, entrepreneurs have been emboldened to introduce innovation in products and processes and enter new geographies. Moreover, diffusion of information, resources and technical proficiencies within industrial clusters has reduced total costs and facilitated technical reforms. Most 
technological improvements in the sector were influenced by demand from large domestic or international buyers or supply-chain partners. In addition to the above benefits, firms within a specific cluster have been able to better utilise the available infrastructure by sharing the same transport mechanism. These clusters even helped the journey of rural artisans with innate skills to self-sufficiency by overcoming their funding and technology-based constraints.

\subsection{Exploring Of Unmapped Potential Clusters Through Cluster Development}

Numerous success stories showcasing the potential of MSMEs have been recorded in India. Many industrial zones across sectors adopted the participatory approach by coming together to reap the enormous benefits of clustering. The event of cluster formation may be classified as natural and artificial. The former is driven by huge demand conditions or a private sector unit, while the latter is supported by favourable infrastructure ecosystem and policies or a large buying undertaken by a public sector initiative. The textile industry, largely operated within industrial clusters, in India is home to more than 70 clusters, accounting for around 80.0 per cent of the total country's production. There are several successful natural clusters across the country. Panipat is home to 75.0 per cent of total blankets produced in the country, the Tirupur contributes 80.0 per cent to total cotton hosiery export, and Agra exports shoes worth USD60.0 million annually. Similarly, Ludhiana has become the hub for production of woolen knitwear, sewing machines and, bicycles and bicycle parts in India. On the other hand, the auto component industry at Gurgaon is an induced cluster. Setting up of Maruti Udyog Ltd.'s public sector car manufacturing unit laid the foundation for the cluster formation. Moreover, petrochemical-based cluster at Vadodara was driven by the establishment of Indian Petrochemical Industries Ltd. (another public sector initiative). Additionally, majority of the gems and jewellery exports come from Surat (Gujarat) and Mumbai (Maharashtra). Likewise, Chennai, Agra and Kolkata are hubs for leather and leather-based products.

\subsection{Efforts of government towards cluster development and marketing promotion}

The numerous advantages of operating in a cluster have prompted several regional and local organisations to take up cluster-based projects and promote smaller firms. The various central government initiatives involve provision of technical aid, grant for technology advancement and marketing assistance to provide a competitive edge to MSME units in the global ecosystem. State governments of Andhra Pradesh, Gujarat, Kerala, Madhya Pradesh and Tamil Nadu have also undertaken cluster development strategies. The early advancements in the field are formation of National Small Industrial Corporation Ltd., Small Industries Development Bank of India, Khadi and Village Industries Commission, The Baba Saheb Ambedkar Hastshilp Vikas Yojana Scheme, United Nations Industrial Development Organisation Cluster Development Programme, State Bank of India's UPTECH Programme, and Rajasthan Chamber of Commerce and Industry, among others. The soft and hard intervention provided due to MSECluster Development Programme, Lean Manufacturing Programme,ISO Certification Programme and other information and communication tools programmes launched by the Government of India would also help industrial clusters in India to improve their productivity. To avail benefits from the above mentioned funding schemes, the government is actively disseminating information amongst rural entrepreneurs. Moreover, schemes and programmes supporting infrastructure, skill set, and entrepreneurship and technology development, coupled with cluster-building activities, would help in optimising the returns and maximising the country's growth in the long term.

\subsection{Dereservation-}

The issue of de-reservation has been a subject of animated debate within government for the last twenty years. The Approach to the Eleventh Five Year Plan notes the adverse implications of reservation of products for exclusive manufacture by the MSEs and recommends the policy of progressive dereservation. To facilitate further investments for technological up gradation and higher productivity in the micro and small enterprises, 654 items have been taken off the list of items reserved for exclusive manufacture by the manufacturing micro and small enterprises in the last few years - reducing it to 21 at present. This has helped the sector in enlarging the scale of operations and also paved the way for entry of larger enterprises in the manufacture of these products in keeping with the global standards.

\subsection{Micro and Small Enterprises Cluster Development Programme}

The Micro and Small Enterprises Cluster Development Programme (MSECDP) is implemented for holistic development of clusters of MSEs. The programme envisages measures for capacity building, skill development, technology upgradation of the enterprises, improved credit delivery, marketing support, setting up of common facility centres, etc., based on diagnostic studies carried out in consultation with cluster units and their collectives and management of cluster-wide facilities by the cluster collectives. Marketing Assistance and Technology Upgradation Scheme for MSMEs: The objective of this scheme is to identify and encourage those clusters of 
MSMEs, which have quality production and export potential and assist them to achieve competitiveness in the national and international markets. The scheme aims at improving the marketing competitiveness of MSME sector by improving their techniques and technology for promotion of exports. The GoI contribution is stipulated as Rs. 19 crore for this scheme. The broad activities planned under the scheme include technology upgradation in packaging, development of modern marketing techniques, competition studies, etc. Technology and Quality Upgradation Support to MSMEs: The objective of the Scheme is to sensitize the manufacturing (MSME) sector in India to upgrade their technologies, usage of energy efficient technologies to reduce emissions of Green House Gases, adoption of other technologies mandated as per the global standards, improve their quality and reduce cost of production, etc., towards becoming globally competitive. The major activities planned under the scheme include Capacity Building of MSMEs Clusters for Energy Efficiency/Clean Development Interventions, Implementation of Energy Efficient Technologies in MSME sector, Setting up of Carbon credit aggregation centres and encouraging MSMEs to acquire product certification licenses from National/International bodies.

\subsection{Marketing and Procurement}

Under Government Stores Purchase Programme, various facilities are provided to enterprises registered with National Small Industries Corporation (NSIC) in order to assist them for marketing their products in competitive environment.

These facilities are :

(i) issue of Tender Sets free of cost;

(ii) exemption from payment of Earnest Money Deposit;

(iii) waiver of Security Deposit upto the Monetary Limit for which the unit is registered; and

(iv) Price preference up to $15 \%$ over the quotation of large-scale units.

(v) In addition to these facilities/benefits, 358 items have also been reserved for exclusive purchase from the MSE Sector.

However, as these guidelines were/are not of a mandatory nature, the same has failed to achieve the desired results. To assist the MSEs in marketing of their products, Section 12 of the new MSMED Act enjoins the formulation of a scheme of preferential procurement of goods/services produced/rendered by MSMEs both at the Central and State/UT levels. Once formulated, the procurement scheme may be more effective in providing the much-needed marketing support that MSEs seek so desperately. Each Ministry/Department, CPSU, etc., would have to make specific mention of the Compliance of the preference policy in its Annual Report to be tabled in Parliament.

\subsection{Export Promotion}

Export promotion from the MSE sector has been accorded a high priority. To help MSEs in exporting their products, the following facilities/incentives are provided:

(i) Products of MSE exporters are displayed in international exhibitions and the expenditure incurred is reimbursed by the Government;

(ii) To acquaint MSE exporters with latest packaging standards, techniques, etc., training programme on packaging for exporters are organised in various parts of the country in association with the Indian Institute of Packaging;

(iii) Under the MSE Marketing Development Assistance (MDA) Scheme, assistance is provided to individuals for participation in overseas fairs/ exhibitions, overseas study tours, or tours of individuals as member of a trade delegation going abroad.

(iv) The Scheme also offers assistance for (a) sector specific market study by MSE Associations/Export Promotion Councils/Federation of Indian Export Organisation; (b) Initiating/contesting anti-dumping cases by MSE Associations; and (c) reimbursement of 75 per cent of the one time registration fee and annual fee (recurring for first three years) charged by GSI India (formerly EAN India) for adoption of Bar Coding.

\section{Conclusion:-}

MSMEs are likely to experience a more conducive landscape going forward, with the government committed to provide momentum to the sector by including it as an integral part of industrial policy. Experts opine the share of MSMEs in the country's GDP would touch double-digits by the end of this decade from the current 8.0 per cent. SMEs' contribution to the country's GDP is expected to increase to 22.0 per cent by 2020 . The anticipated rise can be attributed to policymakers' focus on boosting the country's manufacturing sector and promoting greater role of 
entrepreneurial activity across sectors. This could lead to a wide range of lucrative opportunities for domestic and international investors.

\section{References:-}

1. MSME Overview

2. India Brand equity fund literature

3. Office of DC MSME, Ministry of MSME, Government of India

4. Fourth Census Report 2006-07 